\title{
Media Strengthens Social Stability of Saudi Society
}

\author{
Mohammed bin Saqr Alillaiti ${ }^{1}$ \\ ${ }^{1}$ AROMA Educational Institution, Riyadh, Saudi Arabia \\ Correspondence: Mohammed bin Saqr Alillaiti, AROMA Educational Institution, Riyadh, Saudi Arabia. E-mail: \\ prof.mhdsaqer@gmail.com
}

Received: March 27, 2018

Accepted: September 15, 2018

Online Published: November 27, 2018

doi:10.5539/ies.v11n12p94

URL: https://doi.org/10.5539/ies.v11n12p94

\begin{abstract}
Media in our time is the force behind driving the formation of awareness of society in terms of citizenship and social stability. It builds a society in terms of values, but also destroys beliefs and values that may have been formed ages ago. It is a double-edged weapon. This study aims to present the concept of media, its importance and role in society with regard to social stability and indicate the role of Saudi media in contributing to social stability from the perspective of faculty members in Saudi universities. The Results show that Media in this age is what sets the agenda for the public and is usually subject to media professionals. In addition, Media during the process of formulating its message succumbs to the pressures of its sponsors, regardless of their scientific level and background. In light of the results of this study, the researcher recommends that Saudi media be given the importance of the dialogue methods used in its programs and coverage so that the public can learn how to respect dissenting opinions. This is achieved via setting up a lot of areas for meaningful discussions so that the public can accept it and that there are opinions that must not be marginalized.
\end{abstract}

Keywords: media, stability, social, Saudi, society

\section{Introduction and Background}

Mass media have played a vitally important role in stamping the technological era upon the face of the contemporary world. A variety of communication media have successfully transmitted information with the goal of realizing specific outcomes while simultaneously expanding services, thus reaching beyond national ranges to remote ends of the earth, so much so, that residents of both are currently becoming close neighbors.

In past centuries, this was not the case; human beings lived in small communities, in villages or towns with limited population density, and with limited access to other regions. Large cities were few in number and therefore communication was limited to the confines of a small society. However, subsequent wars, invasions, and human migrations resulted in people becoming more connected to one another; strangers mixed, opinions were shared, and people became influenced by the other's customs. Yet, in spite of this, the personal circle of each member of society remained small.

Media has been understood to be a tool that plays an important role in facilitating communication within the various echelons of society, contributing to both the organization of group relationships and the identification of cultures and ideas, as well as laboring to satisfy the numerous educational, recreational and cultural needs of society. The way these societies evolved, and the way they had been affected by various events and issues that shaped them - each contributing to their building and integration, has been of much interest to social researchers who are now considering social media's effect on human populations.

In order for media to be effective in influencing societal members, they must follow three consecutive stages:

Stage 1: Publicizing information. This refers to clarifying ambiguous or false information and providing information originating from anonymous sources that people may need to know.

Stage 2: Changing Trends. This stage is represented by the shaping of undesirable societal attitudes and trends while strengthening desired ones. This is accomplished through religious and health awareness-raising programs that highlight important current issues. Here, the various media attempt to persuade the individual to either accept or reject the subject matter.

Stage 3: Changing Behavior. The goal here is to change the conduct of the audience and to reach as large audience as possible. 
These three variables occur in sequence, meaning that changing behavior requires changing the individual's perceived misguided perception first, and then changing undesirable trends. Secondly, it is noted that changing attitudes and ideas often occurs if the new trend is based upon creed and values; therefore, media messages must be clear so as not to leave any opportunity for the public to infer meaning that is not intended (Abu Issba', 1995).

Furthermore, media plays an essential role in strengthening social stability by fostering the development of individuals with characteristics that guarantee society's unity and solidarity, thereby bettering their societies. Media in Saudi Arabia is deemed complementary to the stability of society as an institution of the state through which it serves to complete what was started within the community, and in which the principles of good conduct are consolidated. Media link the individual to society by raising one's sense of allegiance and belonging while simultaneously clarifying or reinforcing one's rights and duties towards others in addition to the broader community.

The role of media is to provide the basic knowledge needed by the seeker in order to understand the status of his country and its relationship to the outside world, moreover, to understand the nature of cultural differences within the society, and to recognize and appreciate the struggle of previous generations, and to raise his awareness of the main problems facing his community" (Karen, 2000).

Based on the previous facts, this study was conducted to highlight the role of Saudi media in strengthening social stability in Saudi Arabian society from the perspective of faculty members in a number of Saudi universities (The University of King Abdul Aziz University, King Saud University, the University of Imam Muhammad bin Saud and Umm Al Qura University.

\subsection{Social Stability Measure}

Social stability, as an expression of structural social equilibrium process, is deemed to be one of the topics that specialists in sociology pay special attention to. Stability represents the ability of the system to preserve its existence over time, and to remain in a state of balance through the participation and integration of the system's various sub-institutions which tend towards balance and stability through the mechanisms of adaptation inherent in them. If a change occurs in one of these institutions where its performance is non-functional, it suffers a phase of imbalance.

Balance can be then restored by changing the pattern of use of organizational mechanisms such as media, so that social patterns continue without a sudden or radical change, as well as to prevent any disintegration of the manifestations of social order (Al-Rabai'ah, 1988).In 2005, Carl Minzner revealed that China had suffered from many disturbances in the country, and that many demonstrations had increased unexpectedly causing instability within society, which led the government to inject all of its resources in order to prevent the social and political breakdown that might have occurred. For the Chinese, social stability was the foundation of state continuity. This indicates that the state, prior to the establishment of its political entity, must establish and maintain social stability with all of its indicators, even though they differ as to its definition (Carl Minzner, 2005).

Public opinion in China has shown that all officials elucidated that their most important priority in the country was social stability. Likewise, polls in the United States have shown that political campaigns prioritize social stability in the country, for stability of the social structure is the cornerstone of political stability.

If we were to scrutinize the Arab world, we would hardly see the concept of social stability reflected in much of the literature or in many political speeches, except conjoined with political stability, as many Arab nations deem political and social stability to be one and the same. This is a misguided concept, for political stability is relevant to social stability only as being one of its components and is affected by the latter's impact. In this study,the researcher shall attempt to clarify this concept and its indicators.

Social Stability (Concept, Indicators, and Associated Phenomena)

\section{A-Concept}

Despite the prevalence of both the concept of social stability in social theory and political thought and its importance for practical application, there is no agreement among academics on a unified definition of stability along with its indicators. The definitions and approaches adopted to address this phenomenon vary from one researcher to another according to the methodology and ideology that direct and guide each one's perspective as a researcher (Muhammad, 1989).

The definition of stability in the language dictionary (Qur) is defined as a decision: they decide, and it had been decided on, regarding the place or on the matter; it is both steady and still; it is an expression of the movement preceding stability and tranquility (Al-Sahih, 1996). 
The American Heritage dictionary of English defines the meaning of the word stability as both the resistance to sudden change and to the preservation of balance (Morries, 1981).Social dictionaries also add other possible dimensions to this concept: as a continuation of social patterns in society, without sudden or radical change in any aspect of these patterns (Badawi, 1987).

Atef Ghaith (1988) adds another concept for social stability: The continued existence of social and cultural models in a large community or society without being subjected to sudden or radical change, but social stability does not necessarily imply a stable state of society, - notwithstanding that a stable society - assuming it does exist - should be stable.

Al-Saffar believes that social stability is what puts the nation on a path of unity and provides opportunities for constructive development. He defines social stability as an acceptable system of relations between the forces of the nation and its parties. Contrary to that is a state of turmoil, when these relationships are disrupted, causing hostility, conflict, and struggle (Saffar, 2005.). Saffar's idea addresses social stability from the perspective of the relationship between the State as a system, and its parties represented by the general public.

Brenton (1965) goes further in detailing the concept of social stability. "A stable society does not mean a society in which there is no expression of discontent towards the government nor does it mean existing regimes in which the law is never violated", and "that one has no doubts that even authoritarian autocratic states are capable of reaching such a level."

Brenton's perspective shows that a stable society is not so sound and healthy. It doesn't criticize its government or ruling party, nor its devoid of preaching about its current state of moral degeneration. It is one which has neither imaginary dreams nor is disturbed by turmoil, being one where factories do not close their doors leaving unemployment, nor there are any waves of criminality, nor violation of civil liberties.

To sum up, a stable society is one in which "these types of tensions do not increase dramatically. You may also expect that most people would behave as if they feel that the society - with all of its mistakes - is a successful institution (Ghaith,1988).

Stability, as indicated by some scholars, points out a kind of synergy between a set of interrelated social phenomena. Such support may be apparent or latent, and may be dynamic (renewable) or static (constant).

Social stability term has gained attention among social analysts due to the interest of functional theory in explaining stability and balance within society. The conservative approach manifest in sociology focuses on studying the factors that aid or support a social reality that stands upon cultural and political components. As long as the various social, economic, political, educational and cultural systems are able to perform their functions within society harmoniously and synergistically, thus satisfying the needs of its members, then too will the community be able to continue to thrive.

Based on the review of the academic definition of social stability; social stability is the persistence of social and cultural models and phenomena in society that prevent sudden or radical change. That does not necessarily mean that there is a state of absolute stability because a constant society is a stable one. That is, a society that is undergoing gradual yet adequate changes, capable of achieving re-compatibility without causing disruption or disintegration, is a stable society.

\section{B-Indicators and Dimensions}

The process through which balance and stability are achieved is a shared responsibility that must be observed by all formal and informal institutions, and which can be realized by instilling in the general population the spirit of national allegiance, in addition to a general sense of commitment and loyalty to official authority. This is considered pivotal and fundamental for bringing about integration and balance.

In recent years the notion of stability has become a fateful issue for sociologists, psychologists and politicians as well as other interested parties. Creating a stable society is seen as being necessary now more than ever, and is believed to be achievable by way of proper upbringing and education which appeals to the hearts and minds of society's youth.

Fundamentally, various media include newspapers, radio, internet, or television affect society's attitudes, values, and behavior. Consequently, media influences and shapes ideas related to politics and education as they clarify both the scale of Saudi Arabia's national gains and level of social security.

It is generally understood that when individuals are not productive in their daily lives, their understanding of the magnitude and scope of national gains being made due to political and economic stability is lacking. Therefore, they need to be a constant emphasis on publicizing this information in order to achieve the desired awareness and 
balanced thinking among all citizens.

Sociologist Dur Kaem emphasizes that point in the quote: in order to govern the collective conscience of human behavior, the latter should be formulated and formed from the beginning (Al-Yusuf, 2001).

Once the society stabilizes, social phenomena and systems continue the process of development and evolution; there is a movement away from homogeneity and generalization to variation and specialization. During the transition, social phenomena and systems will be affected by two factors, internal and external (Ubaid, 1999). Internal factors relate to the individual aspect, i.e. all individual characteristics related to the physical, mental and emotional composition of individuals who form the community, as individuals make up the society.

As for the external factors, these are all ones that fall outside the scope of individual characteristics but that have a direct effect on individuals and social phenomena. These factors are the environment, such as the geographical and natural environment, its climatic conditions, location, and other environmental influences. The development and evolution of society is a process that extends to various aspects of social life, from the growth of political unity within the family, tribe, city, society, state authority, nations, etc., to that of economic unity related to domestic, occupational, industrial and financial industries and institutions including joint stock companies and monopolies.

There are also factors that contribute to the stability of society. In general, the way a social system operates and is preserved is a manifestation of the stability of society, and the most important factor related to preserving stability is achieving a reduction of social crime (Bakr, 2001). Social crime comes in various forms, one being murder based on vengeance. Another is debauchery, which is not only a social but also considered a religious crime. Non-educational punitive beating is considered a social crime as is also deliberate neglect in raising children. The imbibing of alcohol is considered both a social and a religious crime. As for theft, most incidences are considered social crimes. Casting the elderly into nursing homes is also believed to be a social crime. So too, are slander, prattling and backbiting. All of these crimes cause the destabilization of society, due to their interfering with social interdependence, which is a key element in realizing stability in society.

In fact, Arab societies are still interrelated; credit may be given to the fact that there is strict adherence to moral and religious ideals and rules in our society. One other factor is the stability and application of laws so that these laws are appropriate for society, for they protect society from crime, preserve the rights of the right holder and regulate political, economic and social relations among its members.

Psychological stability is also a key element. The reasons for the loss of psychological stability are many, such as extreme poverty, family disintegration, and fear of the future, or political and social tyranny that harms society.

Finally, among the factors of stability, each individual member of society is responsible for not neglecting his or her responsibilities. The teacher's job is to educate the student. The social worker addresses social problems of individuals and families. The doctor treats the patient's physical and mental health. The street cleaner cleans roads and streets, removing anything that might harm the sight or have a negative impact on a person's psyche and health.

As for a father, his task is well known; so that of the mother, who ought not relinquish the responsibility of raising the children to the servants.

Both Arabic and foreign studies have dealt with the concept of social stability, but have often avoided identifying the indicators of stability and uncovering its dimensions. Some of these studies might narrow it down to being limited to the stability of the government in terms of the stability of the elements of the governing authority. Others, however, extend it to include the institutional stability in the sense of the continuity of the structural framework of the state in a particular form, such as the monarchy or the republic, the civil or military rule.The broadness may well extend beyond the scope of social and political images, i.e. the absence of political violence from riots, demonstrations, turbulences, political assassinations or civil wars (Al-Fatawi, 1996).

In Anthony's (1999) study, it was found that social stability was related to one of the environmental indicators in society; the existence of solutions to the water problems, i.e. lack of enough water for agricultural and personal needs in South Africa.

Since all these indicators lack clarity and accuracy in terms of their ability to explain the phenomenon of stability, the study hereby depends upon a number of images and indicators that have been previously utilized to establish standards in clarifying the implications and dimensions of social stability, in addition to the semantic content of the study. Here the stability that this study refers to is the structural stability that ensures the continuity of social, cultural and political patterns in society- these patterns being characterized by gradual transformations in order to successfully adapt to the conditions of both internal and external environments and along with tacit rebalancing ensure they do not lead to crises that incur severe structural imbalances. That can be studied through the following 
dimensions and indicators (Adly, 1991):

First: religious belief

Many studies may not consider the subject of religion as one of the indicators of social stability, they tend to deviate to other indicators. But the researcher believes that religion is one of the most important indicators of social stability as it includes all aspects of life within the organization from the top of the pyramid to the fundamentals as represented in the public. Observing the Arab world attentively, it's obvious that the Arab nations are driven to religion instinctively. For them, religion is the solution to all unsettled issues in their societies; indeed, this has been demonstrated by some of the elections that took place in Arab countries such as Palestine, with the victory of Hamas as representative of the Palestinian people, and in Egypt with the victory of the Muslim Brotherhood, both representing the Islamic approach as the model for governance. Religious creed is a common denominator among the members of a single society, as it unites peoples that are geographically far apart. It is an essential element for ensuring internal cohesion as well as in harmonization between societies.

Second: cohesion among members of society (belonging to one country and one society)

There must be cohesion among the members of the community, each of whom feels closely connected to both his homeland and community. A man's feeling of having a functional role in his society gives one a sense of belonging and affiliation, so that the bond between him and other members increases, thus providing cohesion among them and therefore, the cohesion of society as a human unit with certain orientations.

The United Nations, representing the international community, issued the Declaration on Civil and Political Rights and the International Covenant on Economic, Social and Cultural Rights on December $16^{\text {th }}$, 1966. These rights, which provide citizens with a guarantee of opportunities for tranquility and well-being requires them to make an effective contribution to their realization in society.

Third: empathy among people of the same homeland

One of the most important conditions that must be present in any society in order to enjoy social stability is the sympathy of the people of one country. Once this humanitarian bond is established, it constitutes an impenetrable barrier that prevents individuals from harming or assaulting one another. Emotional sympathies extend to those that exist between not only groups but also sects; diversity is inherent and deep within Muslim and Arab societies which are composed of different races, nationalities, religions, sects and intellectual currents.

The fact that Islamic civilization presented in its history a model of tolerance and co-existence with different affiliations has been overshadowed by a later reality of Islamic societies which, being aggravated by this state of diversity, have disrupted good relations between the various groups. The differences which include nationalist and sectarian tendencies have exploded in many regions and the worst cases have seen sectarian strife, where religion is used as a weapon of atonement, mobilization, and incitement, all of which have a negative impact on social stability. Perhaps the wars that took place in Iraq, Lebanon, Afghanistan and Somalia are part of the consequences of this sectarian disease.

Fourth: the dimension of economic security

Social stability itself depends upon economic security which guarantees that citizens can earn a livelihood. This means ensuring useful enduring employment and productive industrial, commercial, and agricultural activity, which in turn allows for the provision of food and clothing in a safe manner that meets an individual's basic needs, thus allowing for a healthy life. Economic security ought to be deemed as one of the most important elements of social stability because it is the cornerstone of a sound social structure. Society cannot settle if people do not have food and water security. A UN report on the world food situation in 1982 showed that five hundred million people lived below the minimum level of food security needed by an individual to be able to live and grow normally, with nearly one million others being in a state of famine (United Nations, 1982).

Ensuring that citizens have minimum nutrition and clothing is a prerequisite for the regularity of human life and thus for the stability of society, which is why countries and international organizations are currently focusing on food security both locally and globally. We know that societies experiencing a sharp rise in food prices revolt, as there have been revolutions in some Arab societies, including the one dubbed "The revolution of bread". There were also strikes due to the low level of wages paid to state employees.

Fifth: the dimension of heritage

Heritage cannot be overlooked as a fifth dimension. Heritage is the set of values and traditions that includes human experiences, creations, and the legacy of culture and thought that has been extended over the ages. Evidently, it is indisputable that all nations who advance and seek progress are those who care about the legacy of their fathers and 
grandfathers, and who see in that heritage the basis on which to build the present.

It is believed that heritage contains proof of identity with the values and traditions transmitted from one generation to the next, an identity that some nations have fought to preserve so as not to evanesce with other cultures. Thus, the successor put into practice the reason behind the success of the predecessor (Al-Fil, 2005).Most societies try to defend their beliefs and values, believing that these represent pillars of social stability, therefore imposing prohibitions on any form of change or compromise.

Perhaps the indicators of social stability and dimensions do not stop at these elements, but exceed beyond that of the vision of the researcher in his interpretation of stability. To conclude, society will enjoy extensive stability whether beginning with the role of the individual or the role of the family, as both have a role and function as family being considered one of the pillars of society. Some believe that social stability lies in the creation of a sort of a social solidarity and the elimination of all the problems that both the individual and society are subjected to. Additionally, social stability contributes significantly to the process of national development and upbringing, so the process is one of reciprocity between the two phenomena. In order to maintain social stability, addressing negative issues and problems has become a top scientific and political priority at the level of political decision-making. Therefore, the task of redesigning national concepts to meet the requirements and needs of the age while encountering the many challenges and risks presented is a common mission aimed at achieving the interests of the state by maintaining the security and social stability of the homeland.

\subsection{Study Significance}

The importance of this study is in its attempt to assess the level of media's influence on strengthening social stability in Saudi Arabia, which may provide the decision makers with the necessary and essential information to either activate the role of media, or to strengthen elements of positive performance within the official media. Moreover, the results of this study and its recommendations may be used to explain the strengths and weaknesses of Saudi media, and it attempts to provide practical mechanisms to activate the role of media and its contribution to strengthening social stability.

\subsection{Study Rationale}

The justification for this study is as follows:

- The importance of activating the role of media in strengthening political stability in light of the emergence of terrorism phenomena, which is a potential threat to Saudi Arabia's security and stability in the region.

- $\quad$ - The need to both determining how media can be used to achieve societal development, prosperity and stability, as well as understanding the mechanisms for bringing these about, accurately and clearly.

\subsection{Study Objectives}

This study aims to:

- $\quad$ Present the concept of media, its importance and role in society with regard to social stability.

- Define the concept of and importance of maintaining social stability.

- Indicate the role of Saudi media in contributing to social stability from the perspective of faculty members in Saudi universities.

- Pursue the extent of differences between the perceptions of faculty members in Saudi universities regarding the role of media in strengthening social stability in Saudi Arabian society, and the extent to which this difference, if any, is related to some independent variables (such as qualifications, monthly income, and the party in which they work), related to these categories.

- Come up with a set of results, and propose recommendations that are suitable for the purposes of the study.

\subsection{Study Questions}

This study tries to answer the following questions:

- How do faculty members in Saudi universities view the official Saudi media?

- How do faculty members in Saudi universities view the role of Saudi official media in promoting social stability?

- Does the perspective of faculty members in Saudi universities differ, depending on individual characteristics such as level of education, monthly income, and the university in which they work, on the role of Saudi media in encouraging social stability? 


\section{Method}

This section describes the method and procedures used in the current study, in terms of methodology, community, sample, study tools, variables, and statistical processing to answer the study questions.

\subsection{Methodology}

This study relied on descriptive analytical methodology in collecting data to answer its questions. A questionnaire was used to gather opinions and responses of faculty members on the role of media in strengthening social stability in Saudi Arabian society.

\subsection{Population}

The study population is comprised of the teaching staff members, which included all faculty members at King Abdul Aziz University, King Saud University, Imam Muhammad Bin Saud University and Umm Al Qura University in the Sociology and Media Departments, numbered 223 in total.

\subsection{Sample}

A random sample $80 \%$ of the faculty members was selected. Thus the study sample consisted of 178 faculty members. After the questionnaire was distributed to the sample, a total of 150 questionnaires were recovered and edited.

\subsection{Tools}

For the purposes of this study, the researcher developed a questionnaire to identify the perceptions of faculty members in Saudi universities on the role of Saudi media in strengthening social stability, drawing upon previous studies and theoretical literature. Based on the Likert scale, the answer was always given (5) degrees, often (4) degrees, sometimes (3) degrees, rarely (2) degrees, never, (1) degree.

The study tools consisted of two tools, as follows:

1) Questionaire: aims to identify Saudi media and the role played in society through the programs offered. The tool consisted of (20) paragraphs to measure the role of media in Saudi society. These paragraphs were developed from the principals of the main media literature.

2) Social Stability Scale: aims to identify the role of Saudi media in helping to establish stability within Saudi society through the programs it provides. The tool consists of (20) paragraphs, which were developed using as a basis, the main literature available; however, studies researching social stability were very few to be found.

\subsection{Validity}

The study tool was presented to ten specialists in the field of sociology and media in Jordanian and Saudi universities for the purpose of checking clarity and suitability of the items of the tool. Each was bid to judge each paragraph in order to validate the measurement of media tool, as well as to make appropriate adjustments, all of which was considered by the researcher before the questionnaire was issued in its final form.

\subsection{Stability}

The study tool was applied to a survey sample from the study population and outside it. It consisted of 10 faculty members, and after two weeks the tool was applied again to determine the stability of the study instrument based on Pearson correlation coefficient.

The stability of the internal consistency coefficient of the study instrument was extracted as well - according to the responses of the sample of the study - to determine the degree of compatibility based on the formula of Cronbach Alpha.

The outcome percentage pertaining to the field of media ( 0.85$)$ and pertaining to social stability rated of $(0.91)$ was considered acceptable for study purposes.

Table 1. Cronbach's internal consistency coefficient of the study tool

\begin{tabular}{ccc}
\hline Domain & Internal consistency & Repetition stability \\
\hline Media as a whole & 0.85 & 0.84 \\
Social stability as a whole & 0.91 & 0.88 \\
\hline
\end{tabular}




\subsection{Reliability}

To extract the semantics of the construction accuracy of the scale, the correlation coefficients of the measurement scale were extracted with the total score in a sample consisting of 10 faculty members. Where the analysis of the paragraphs of the scale and the calculation of the coefficient of discrimination of each of the other paragraphs were analyzed, the coefficient of discrimination represents a sign of truth for each paragraph in the form of correlation coefficient between each paragraph and the total degree on the one hand, and between each paragraph and its link to the dimension, as well as between each dimension and the overall degree, on the other. The correlation coefficients ranged between a ratio of $(0.37-0.77)$ for media and $(0.30-0.86)$ for social stability.

Table 2. The correlation of media paragraphs with the tool

\begin{tabular}{llc}
\hline & & Media as a \\
whole \\
\hline 1 & I pore over media at a specific time. & .38 \\
2 & Media regularly presents public issues. & .58 \\
3 & Media takes into consideration the wishes of members of the community. & .67 \\
4 & Media administrations rely on achieving the interests of the homeland. & .37 \\
5 & Saudi media seeks to increase the presentation of information materials on national issues. & .74 \\
6 & There is a correlation between the quality of materials presented in Saudi media and the duration of the presentation of & .77 \\
7 & those materials. & .66 \\
8 & I think that Saudi media is inactive in its role as a means of support for civil society institutions. & .58 \\
9 & There is a general policy of repeating programs aimed at covering both local and regional Arab issues by Saudi media & .63 \\
& departments. & .39 \\
10 & I think that the nature of media material provided by Saudi media is not up to the required level. \\
11 & Saudi media is characterized by honesty and realism. & .38 \\
12 & Saudi media gains the confidence of all segments of Saudi society. & .47 \\
13 & Saudi media takes into consideration the different cultures of the Arab peoples \\
14 & Saudi media is interested in marketing national and Arab issues globally \\
15 & Saudi media allows the participation of members of Saudi society in addressing local and national issues. \\
16 & I follow the news from Saudi media on a daily basis. \\
17 & I care a lot about following the news and events of Saudi society through the local media. \\
18 & I presume that Saudi media has created social and political awareness in individuals. \\
19 & Saudi media has conscious insight into and is aware of the dangers that threaten my country. \\
20 & Security issues are an important and fundamental element in my follow-up of Saudi media. & .41 \\
\hline &
\end{tabular}

Table 3. Linkages of social stability means with the tool

\begin{tabular}{llc}
\hline & & $\begin{array}{c}\text { Social stability as } \\
\text { a whole }\end{array}$ \\
\hline 1 & I think that media plays a large role in reducing unemployment. & .54 \\
2 & Media interference contributes to a reduction in divorce. & .54 \\
3 & Media contributes to raising awareness within Saudi family. & .32 \\
4 & Media promotes good human relations among members of Saudi Arabian community. & .56 \\
5 & Saudi media provides educational programs on poverty. & .61 \\
6 & Media contributes to the preservation of customs and traditions of Saudi Arabian community. & .53 \\
7 & Media contributes to preserving the values of Saudi Arabian community. & .45 \\
8 & Media addresses citizens' problems daily. & .35 \\
9 & Media provides secure communication channels between members of Saudi Arabian community and civil & .65 \\
& society organizations so that they can resolve issues. & .76 \\
10 & Saudi media presents the perceptions of various segments of Saudi Arabian society towards local and national \\
11 & issues. & .80 \\
12 & Saudi media cares about achieving socialization of the members of society. & .70 \\
13 & Saudi media discusses the most important social changes in Saudi Arabian society. \\
14 & Media crystallizes society's view of contemporary social issues. & .30 \\
\hline
\end{tabular}




\begin{tabular}{lll}
\hline 15 & Saudi media cooperates in addressing contemporary social issues. \\
16 & Saudi media focuses on analyzing the roles of Saudi family members. \\
17 & Saudi media shows the importance of social solidarity in Saudi Arabian society. & .51 \\
18 & Saudi media contributes to the development of qualities of compassion and respect among members of Saudi & .79 \\
19 & Arabian community. & Saudi media develops a spirit of cooperation and harmony among members of Saudi Arabian community. \\
20 & Saudi media provides realistic solutions to the social problems of the community. & .73 \\
\hline
\end{tabular}

\subsection{Analysis}

The appropriate statistical methods were used to answer the study questions which related to the following: frequency, percentage, mean, standard deviation, $T$ test, mono-variance analysis, and spectral comparisons which were used in the case of statistically significant differences. Frequency, percentages, mean, standard deviations, $\mathrm{T}$ test, the analysis of mono-variance analysis, and dimensional comparisons were used in a quasi-method in the case of statistically significant differences.

\section{Results and Discussion}

\subsection{First Question: How Do Faculty Members in Saudi Universities View the Official Saudi Media?}

To answer this question, means and standard deviations of the perspectives of faculty members in Saudi universities were calculated to the official Saudi media. Table 4 below illustrates the Means and Standard Deviations of the perspectives of faculty members in Saudi universities towards the official Saudi media.

Table 4. Means and standard deviations of the perspectives of faculty members in Saudi universities towards the official Saudi media

\begin{tabular}{|c|c|c|c|c|}
\hline Rank & Number & Paragraphs & $\mathrm{M}$ & S.D. \\
\hline 1 & 1 & I view media at a specific time. & 4.10 & .88 \\
\hline 2 & 5 & Saudi media seeks to increase the presentation of information materials on national issues. & 4.07 & .81 \\
\hline 3 & 4 & Media administrations depend upon the interests of the nation. & 4.06 & .96 \\
\hline 4 & 2 & Media regularly presents public issues. & 3.96 & .96 \\
\hline 5 & 17 & I am keen on following the news and events in Saudi society through the local media. & 3.84 & .97 \\
\hline 6 & 7 & I think that Saudi media fulfills its role as a means of support for civil society institutions. & 3.67 & 1.06 \\
\hline 7 & 20 & Security issues are an important and fundamental element in my follow-up on Saudi media. & 3.66 & 1.11 \\
\hline 8 & 8 & Saudi media have frequently repeated reporting on social programs. & 3.65 & .91 \\
\hline 9 & 9 & There is a general policy to repeat programs aimed at local and Arab issues by Saudi media departments. & 3.58 & 1.07 \\
\hline 10 & 11 & Saudi media is characterized by honesty and realism. & 3.55 & .87 \\
\hline 11 & 16 & I follow the news from Saudi media on a daily basis. & 3.54 & 1.16 \\
\hline 12 & 3 & Media takes into consideration the wishes of members of Saudi Arabian community. & 3.47 & .98 \\
\hline 13 & 6 & $\begin{array}{l}\text { There is proportionality between the quality of materials presented in Saudi media and the length of the } \\
\text { presentation of these materials. }\end{array}$ & 3.42 & .87 \\
\hline 14 & 19 & Saudi media is conscious of and has insight into the dangers that threaten my homeland. & 3.39 & 1.25 \\
\hline 15 & 15 & $\begin{array}{l}\text { Saudi media allows the participation of members of Saudi society to participate in addressing local and } \\
\text { national issues. }\end{array}$ & 3.37 & 1.03 \\
\hline 16 & 12 & Saudi media gains the confidence of all segments of Saudi society. & 3.28 & .89 \\
\hline 17 & 13 & Saudi media takes into consideration the different cultures of the Arab peoples. & 3.17 & 1.09 \\
\hline 18 & 14 & Saudi media is interested in marketing national and Arab issues globally. & 3.16 & 1.06 \\
\hline 19 & 18 & I believe that Saudi media has created social and political awareness among individuals. & 2.96 & 1.19 \\
\hline \multirow[t]{2}{*}{20} & 10 & I deem that the nature of media material provided by Saudi media is not up to the required level. & 2.73 & .87 \\
\hline & & Media as a whole. & 3.54 & .60 \\
\hline
\end{tabular}

Results show means of the 20 paragraphs of this question ranged between 2.71 as a minimum and 4.11 as a maximum. As a result, the attitudes of the faculty members towards the adoption of media to achieve the interest of the country were equal to 4.06 . This shows that the attitudes of faculty members towards the adoption of media departments to achieve the interest of the country, as well as increasing the presentation of information materials on the issues of the country, were positive trends. The researcher attributed this to the fact that the programs and media outlets intensify their media campaigns through the presentation of programs and national coverage, using 
all media.

The attitudes of the faculty members towards the nature of media material provided by Saudi media being at the required level equals 2.71, while their attitudes toward Saudi media as creating social and political awareness of individuals equals 2.95. This explains that the negative trends both toward the nature of media material provided, as well as the belief that Saudi media output is responsible for creating social and political awareness, can be attributed to the following reasons among which:

A-The information materials presented are not based on studies, but rather either on particular reactions to specific ideas or were compiled in an improvised manner which may have caused either the loss of a clearly defined goal, or a lack of clarity in the way that media material was developed.

B-Media is one of the means that helps to create social and political awareness in individuals; however, it is not the only means. Higher education as well as the mosque, among others, has an influential role to play. Consequently, many faculty members may not count primarily on Saudi media to acquire knowledge.

The study agreed with the study of Al-Manea (1997) in the ineffectiveness of media planning in some areas of development, and counted the effectiveness of television and newspapers in defining the services of the social center.

\subsection{Second Question: How Do Faculty Members in Saudi Universities View the Role of Saudi Official Media in Promoting Social Stability?}

To answer this question, Means and Standard Deviations of faculty members' responses were extracted. Table 5 illustrates this.

Table 5. Means and standard deviations of Saudi university faculty members' view on social stability in Saudi society

\begin{tabular}{|c|c|c|c|c|}
\hline Rank & Number & Paragraphs & M. & S.D. \\
\hline 1 & 7 & Media contributes to preserving the values of Saudi Arabian community. & 3.61 & .98 \\
\hline 2 & 6 & Media contributes to the preservation of the customs and traditions of Saudi Arabian community. & 3.57 & .97 \\
\hline 3 & 13 & Saudi media discusses the most important social changes in Saudi Arabian society. & 3.37 & 1.00 \\
\hline 4 & 17 & Saudi media indicates the importance of social solidarity in Saudi Arabian society. & 3.31 & .94 \\
\hline 5 & 14 & Media crystallizes society's view of contemporary social issues. & 3.27 & .99 \\
\hline 6 & 3 & Media contributes to raising awareness within Saudi family. & 3.25 & .88 \\
\hline 7 & 15 & Saudi media collaborates in addressing contemporary social issues. & 3.24 & .96 \\
\hline 8 & 4 & Media promotes human relations among members of Saudi Arabian community. & 3.23 & .97 \\
\hline 8 & 12 & Saudi media focuses on the role of the family in Saudi social system. & 3.23 & 1.01 \\
\hline 10 & 18 & $\begin{array}{l}\text { Saudi media contributes to the development of feelings of compassion and respect among members of } \\
\text { Saudi Arabian community. }\end{array}$ & 3.18 & 1.00 \\
\hline 11 & 9 & $\begin{array}{l}\text { Media provides secure communication channels between members of Saudi Arabian community and civil } \\
\text { society organizations for resolving issues. }\end{array}$ & 3.17 & .99 \\
\hline 12 & 11 & Saudi media is interested in achieving the socialization of society's members. & 3.15 & .95 \\
\hline 13 & 10 & $\begin{array}{l}\text { Saudi media presents the perceptions of various segments of Saudi Arabian society towards local and } \\
\text { national issues. }\end{array}$ & 3.14 & 1.04 \\
\hline 14 & 19 & Saudi media develops a spirit of cooperation and harmony among members of Saudi Arabian community. & 3.13 & 1.01 \\
\hline 15 & 8 & Media addresses citizens' problems daily. & 3.01 & .96 \\
\hline 16 & 1 & I think that media plays a major role in reducing unemployment. & 2.99 & 1.14 \\
\hline 17 & 20 & Saudi media provides realistic solutions to social problems of members in the community. & 2.97 & .97 \\
\hline 18 & 16 & Saudi media focuses on analyzing the roles of Saudi family members. & 2.93 & 1.06 \\
\hline 19 & 5 & Saudi media provides educational programs on poverty. & 2.80 & .96 \\
\hline \multirow[t]{2}{*}{20} & 2 & Media interference contributes to the reduction of divorce. & 2.74 & .96 \\
\hline & & Social stability as a whole. & 3.16 & .72 \\
\hline
\end{tabular}

The results of the second question, as shown in Table 5, had denoted that the mean average for each of the 20 paragraphs of this question ranged between 2.72 minimum and 3.60 maximum. Accordingly, the attitudes of faculty members towards the contribution of media in preserving the values of Saudi Arabian society were equal to 3.60. Their attitudes towards the contribution of Saudi media to the preservation of the customs and traditions of Saudi Arab society were equal to 3.57 . 
This shows that faculty member attitudes both towards media in preserving the values of Saudi Arabian society, and towards media's contribution to the preservation of the customs and traditions of Saudi Arabian society have been positive - compared to other paragraphs.

The researcher attributed this to the fact that one of the main functions of media is to preserve those values, customs and traditions, this being why media from many nations try to communicate to the world the customs and values their societies hold dear, in order to facilitate an understanding of their communities. In Saudi Arabia these values and customs are rooted in Islamic teachings and influenced by the existence of the two Holy Mosques.

The attitude of the faculty members to the question of media involvement contributing to the reduction of divorce were equal to 2.72 and their attitude towards Saudi media providing educational programs on poverty equaled 2.75. This indicates that both of these negative attitudinal trends, the former regarding media intervention contributing to a reduction in divorce, the latter regarding media providing educational programs on poverty are attributed to several factors, including the following:

Saudi Arabian society considers that the individuals with a high income and living in luxury call on media to ignore this reality, or at least to downplay that knowledge even though they are aware that there are poor people within Saudi Arabian society.

Also, many wealthy people have been assisting the poor, although they are not well known. Recently, it has been noted that some newspapers have been publishing information on the suffering of many poor people which has brought a rapid response from philanthropists.

Saudi media did not address divorce except in a simple way and in the form of ratios and also did not broach remedial solutions to the problem. That is probably attributed to the fact that the concept of privacy for such a subject and the term (homes are secrets) is still predominant in the mentality of faculty members.

This study has agreed with Abu Libda (2005) on the impact of media on social stability, considering that globalization is having an impact on social stability. Perhaps one of the tools of globalization is media and its various means. The study likewise has agreed with William and Ratner (1999) on the role that media can play to preserve the values within society.

3.3 Third Question: Does the Perspective of Faculty Members in Saudi Universities Differ, Depending on Individual Characteristics such as Level of Education, Monthly Income, and the University in Which They Work, on the Role of Saudi Media in Encouraging Social Stability?

To answer this question, Means and Standard Deviations of the perceptions of the faculty members have been extracted in relation to both Saudi media and social stability according to the variables of the level of education, monthly income and the university in which they work. 
Table 6. Means and standard deviations of faculty members' perceptions about Saudi media and social stability according to some variables (level of education, monthly income, and the university in which they work)

\begin{tabular}{|c|c|c|c|c|}
\hline & & & Media as a whole & Social stability as a whole \\
\hline \multirow{6}{*}{ Education } & \multirow{2}{*}{$\mathrm{BA}$} & Q & 3.04 & 2.54 \\
\hline & & $\mathrm{P}$ & .53 & .64 \\
\hline & \multirow{2}{*}{ M.A. } & Q & 2.82 & 2.60 \\
\hline & & $\mathrm{P}$ & .63 & 1.02 \\
\hline & \multirow{2}{*}{ Ph.D. } & Q & 3.38 & 3.11 \\
\hline & & $\mathrm{P}$ & .56 & .62 \\
\hline \multirow{10}{*}{ Income } & \multirow{2}{*}{ From 5000 to 9,999} & Q & 3.36 & 3.22 \\
\hline & & $\mathrm{P}$ & .72 & .83 \\
\hline & \multirow{2}{*}{ From 10,000 to 14999} & Q & 2.94 & 2.65 \\
\hline & & $\mathrm{P}$ & .68 & .95 \\
\hline & \multirow{2}{*}{ From 15000 to 19,999} & Q & 3.22 & 2.81 \\
\hline & & $\mathrm{P}$ & .43 & .38 \\
\hline & \multirow{2}{*}{ From 20,000 to 24,999} & Q & 3.39 & 2.99 \\
\hline & & $\mathrm{P}$ & .14 & .48 \\
\hline & \multirow{2}{*}{ Of 25,000 and more } & Q & 3.48 & 3.11 \\
\hline & & $\mathrm{P}$ & .04 & .10 \\
\hline \multirow{8}{*}{ The University } & \multirow{2}{*}{ King Saud } & $\mathrm{Q}$ & 3.30 & 3.04 \\
\hline & & $\mathrm{P}$ & .52 & .67 \\
\hline & \multirow{2}{*}{ Imam Mohammad Bin Saud } & Q & 2.94 & 2.43 \\
\hline & & $\mathrm{P}$ & .66 & .82 \\
\hline & \multirow{2}{*}{ King Abdul-Aziz } & $\mathrm{Q}$ & 3.31 & 3.10 \\
\hline & & $\mathrm{P}$ & .60 & .64 \\
\hline & \multirow{2}{*}{ Umm al-Qura } & $\mathrm{Q}$ & 3.25 & 3.03 \\
\hline & & $\mathrm{P}$ & .69 & .82 \\
\hline
\end{tabular}

$\mathrm{Q}=$ mean, $\mathrm{P}=$ standard deviation.

Table 6 shows an apparent discrepancy in the means and standard deviations of the perceptions of faculty members in relation to both Saudi media and social stability which is related to different categories of variables. The first being the level of education (BA, MA, PhD); second, their monthly income which ranges from being less than 5000 , then from 5000 to 9999 , from 10,000 to 14999 , from 15,000 to 19999 , from 20000 to 24999 , up to 25000 or more. The third variable relates to each participating member's University (King Saud University, Imam Muhammad bin Saud University, King Abdul Aziz University or Umm Al Qura University).

To illustrate the significance of statistical differences between the mean, the analysis of mono-variance was used as in tables $(7,9$, and 10$)$.

Table 7. Analysis of mono-variance of the impact of the level of education in Saudi media and social stability from the faculty members' perceptions

\begin{tabular}{ccccccc}
\hline & The source & Total squares & Degrees of freedom & Average squares & Value P & Statistical significance \\
\hline \multirow{4}{*}{ Media as a whole } & Between groups & 8.459 & 2 & 4.230 & & \\
& Within groups & 48.053 & 147 & .327 & & .000 \\
& Total & 56.512 & 149 & & & \\
Social stability as a whole & Between groups & 9.342 & 2 & 4.671 & \multirow{2}{*}{8.987} & .000 \\
& Within groups & 76.400 & 147 & .520 & & \\
& Total & 85.742 & 149 & & & \\
\hline
\end{tabular}


Table 8. Dimensional comparisons of the impact of educational level

\begin{tabular}{llcccr}
\hline & & Mean & Bachelor & Master & Doctorate \\
\hline \multirow{4}{*}{ Media as a whole } & BA & 3.04 & & & \\
& M.A. & 2.82 & .23 & & \\
\multirow{5}{*}{ Social stability as a whole } & Ph.D. & 3.38 & .34 & $.57^{*}$ & \\
& BA & 2.54 & & & \\
& M.A. & 2.60 & .06 & & \\
& Ph.D. & 3.11 & $.58^{*}$ & $.52^{*}$ & \\
\hline
\end{tabular}

First variable: education

There are statistically significant differences $(\alpha=0.05)$ between the master's and doctoral degrees, and the differences were in favor of the doctorate class in the category of media as a whole. There was a presence of statistically significant differences $(\alpha=0.05)$ between the doctoral group on the one hand and the bachelor and master groups on the other. The differences were in favor of the doctoral degree in social stability as a whole.

The researcher attributed this to the ability of faculty members who hold a doctorate to assess the situation more and on account of the knowledge and the aptitude of the totality of variables.

Second variable: Income

Table 9. Analysis of monotonous impact of income on Saudi media and social stability from faculty members' perceptions

\begin{tabular}{lcccccc}
\hline & Source & Total squares & $\begin{array}{c}\text { Degrees of } \\
\text { freedom }\end{array}$ & $\begin{array}{c}\text { Average } \\
\text { squares }\end{array}$ & Value P & $\begin{array}{c}\text { Statistical } \\
\text { significance }\end{array}$ \\
\hline \multirow{3}{*}{ Media as a whole } & Between groups & 4.677 & 4 & 1.169 & 3.270 & .013 \\
& within groups & 51.835 & 145 & .357 & & .005 \\
& Total & 56.512 & 149 & & & \\
Social stability as a whole & Between groups & 8.39 & 4 & 2.098 & 3.932 & .533 \\
& within groups & 177.351 & 145 & & \\
& Total & 85.742 & 149 & & & \\
\hline
\end{tabular}

Table 10. Dimensional comparisons of income effect on Saudi media and social stability from faculty members' perceptions

\begin{tabular}{|c|c|c|c|c|c|c|c|}
\hline Variable & Categories & Mean & $\begin{array}{l}\text { From } \\
5000 \\
\text { Up to } \\
9999\end{array}$ & $\begin{array}{c}\text { From } 10,000 \\
\text { Up to } \\
14,999\end{array}$ & $\begin{array}{l}\text { From } \\
15.000 \\
\text { Up to } \\
19,999\end{array}$ & $\begin{array}{l}\text { From } 20,000 \\
\text { Up to } \\
24,000\end{array}$ & Of 25,000 and more \\
\hline \multirow{5}{*}{ Media as a whole } & From 5000 to 9999 & 3.36 & & & & & \\
\hline & From 10,000 to 14999 & 2.94 & $.42 *$ & & & & \\
\hline & From 15000 to 19999 & 3.22 & .14 & .28 & & & \\
\hline & From 20000 to 24999 & 3.39 & .03 & .45 & .17 & & \\
\hline & Of 25,000 and more & 3.48 & .12 & .53 & .26 & .09 & \\
\hline \multirow{5}{*}{ Social stability as a whole } & From 5000 to 9999 & 3.22 & & & & & \\
\hline & From 10,000 to 14999 & 2.65 & $.57^{*}$ & & & & \\
\hline & From 15000 to 19999 & 2.81 & .41 & .16 & & & \\
\hline & From 20000 to 24999 & 2.99 & .23 & .34 & .18 & & \\
\hline & Of 25,000 and more & 3.11 & .11 & .46 & .30 & .12 & \\
\hline
\end{tabular}

* Function at significance level $(\alpha=0.05)$.

There were statistically significant differences at $(\alpha=0.05)$ between the category of 5000 to 9999 and 10,000 to 14999; and the differences were in favor of the category from 5000 to 9999 for media as a whole. There were statistically significant differences at $(\alpha=0.05)$ within the category of 5000 to 9999 . There were statistically significant differences at $(\alpha=0.05)$ between the category of 5000 to 9999 and 10,000 to 14999; the differences were in favor of the category of 5,000 to 9999 for social stability. 
The researcher attributed this to the fact that those who have little income compared to the rest of the faculty may believe that the status quo is excellent for them and therefore do not aspire to change. In addition, their corresponding lower level of education may prevent them from comparing or including the experiences of other countries. For example, the holder of the master's degree is not like the holder of a doctorate in his understanding of media situation. More than that, it is possible and even probable that the master's thesis holder depends more on internal than external media. Perhaps the language is another reason for this by not relying on other channels or media.

Third variable: The University

Table 11. Analysis of the mono-variance of the impact of the university on Saudi media and social stability from the faculty members' perceptions

\begin{tabular}{|c|c|c|c|c|c|c|}
\hline & The source & Total squares & $\begin{array}{c}\text { Degrees } \\
\text { of freedom }\end{array}$ & Average squares & Value P & Statistical significance \\
\hline \multirow{3}{*}{ Media as a whole } & Between groups & 2.646 & 3 & .882 & 2.390 & .071 \\
\hline & within groups & 53.866 & 146 & .369 & & \\
\hline & Total & 56.512 & 149 & & & \\
\hline \multirow{3}{*}{ Social stability as a whole } & Between groups & 8.541 & 3 & 2.847 & 5.384 & .002 \\
\hline & within groups & 77.201 & 146 & .529 & & \\
\hline & Total & 85.742 & 149 & & & \\
\hline
\end{tabular}

Table 12. Dimensional comparisons to explain the impact of university on social stability

\begin{tabular}{lccccc}
\hline & Mean & King Saud & Imam & Abdel-Aziz & Umm al-Qura \\
\hline King Saud & 3.04 & & & & \\
Imam & 2.43 & $.62^{*}$ & & & \\
Abdel-Aziz & 3.10 & .05 & $.67 *$ & & \\
Umm al-Qura & 3.03 & .02 & $.60^{*}$ & .07 & \\
\hline
\end{tabular}

* Function at significance level $(\alpha=0.05)$.

There are no statistically significant differences at $(\alpha=0.05)$ attributed to the university in each of media as a whole. The researcher attributed this to the fact that all universities and their employees most likely have similar perspectives on general issues and so therefore similar trends in the findings would be reasonable.

\section{Conclusion}

After discussing, analyzing the data, and reviewing the previous studies related to the subject of the current study, the following conclusions have been reached:

- Media in our time is the force behind driving the formation of awareness of society in terms of citizenship and social stability.

- Media is what builds a society in terms of values, but also destroys beliefs and values that may have been formed ages ago. It is a double-edged weapon.

- Media in this age is what sets the agenda for the public and is usually subject to media professionals.

- Media during the process of formulating its message succumbs to the pressures of its sponsors, regardless of their scientific level and background.

\section{Recommendations}

In light of the results of this study, the researcher recommends that Saudi media be given the importance of the dialogue methods used in its programs and coverage so that the public can learn how to respect dissenting opinions. This is achieved via setting up a lot of areas for meaningful discussions so that the public can accept it, and that there are opinions that must not be marginalized.

More over the study recommends encouraging Saudi media's interest in the concept of citizenship and corresponding values of affiliation and democracy, as the results of the study show that there has been a lack of emphasis on these. This may simply be due to media's own lack of understanding of their importance, or else their 
lack of conviction.

In addition, it is recommended that Saudi media increases its participation in forums that call for citizenship and social stability in all its indicators and not be limited to one means. Also, establishing a center of studies that will measure the reactions of the public to the programs offered, followed by the development of necessary plans for their implementation.

Finally, the current study recommends engaging the interest of specialized media which can guide the public according to certain policies to be implemented, since media is not just about show, pictures and production. To add, establishing training centers for media professionals in their institutions will improve their performance.

\section{References}

Abu Esba, S. (1995). Communication, Media and Contemporary Societies. Amman: Dar Aram for Studies.

Adly, E. (1991). Sociology of security; Security and Society. Alexandria: Dar al-Ma'rifah Al-Jamie'yah.

Akkad, L. (2000). Introduction to Communication Theories and Methods. Damascus: University of Damascus.

Al-Bakr, M. (2001). Activating the role of social control institutions in light of contemporary social and economic changes. Arab Journal of Security Studies and Training, 16(32).

Al-Batriq, N. (2004). Media and Society in the Age of Globalization. Cairo: Dar Ghareeb.

Al-Fatawi, A. (1966). Social and Political Stability in Jordan: An Analytical Study in Light of the Concept of Balance (MA thesis, University of Jordan. Amman).

Al-Mennea, H. (1987). Effectiveness of Media Planning in Some Areas of Urban Community Development (MA thesis, King Abdul-Aziz City for Science and Technology. Riyadh, Saudi Arabia).

Al-Qulayni, F., Al-Farnawi, M., Al-Johari, H., Agha, U., \& Al-Johari, M. (2001). Media Sociology (1st ed.). Cairo: Dar Al-Qahirah.

Al-Rabaieh, A. (1988). Factors and Implications of Development: An Applied Study in Rural Jordan. Amman, Jordan University.

As-Saffar, H. (2005). Political and social stability: Its necessity and its guarantees. Beirut: Ad-dar Al-Arabia for Science.

Brenton, C. (1965). The Revolution: its Elements \& Analysis of its Results. Beirut: Dar al-Kitab al-Arabi.

Carroll, W. K., \& Ratner, R. S. (1999). Media Strategies and Political Projects: A Comparative Study of Social Movements. Canadian Journal of Sociology/Cahiers Canadiens de Sociologie, 24(1), 1-34. https://doi.org/10.2307/3341476

Geddnes, A. (2005). Sociology with Arabic Inputs. Beirut: Center for Arab Unity Studies.

Ghaith, M. (1988). Sociology Dictionary. Alexandria: Dar al-Ma'rifah Al-Jamie'yah.

Hatem, M. (1972). Media and Publicity Theory and Experiences. Cairo: The Anglo-Egyptian Library.

Hill, C. (1987). Affiliation Motivation That People Need but in Different Ways. Journal of Personality and Social Psychology, 52(5), 1008-1018. https://doi.org/10.1037/0022-3514.52.5.1008

Homana, G., Carolyn, B., \& Judith, T. (2006). Assessing School Citizenship Education Climate: Implications for the Social Studies. Circle Working Paper (48): Center for Information \& Research on Civic Learning \& Engagement, University of Maryland.

Hughes, T., Norman, L., William, A., \& David, H. (2007). Primary and Secondary Education in Canada and Poland-Compared: International Implications. The Lamar University Electronic Journal of Student Research, 13(2).

Ibn Manzoor, A., \& Abi al-Fadl, Y. (1994). Arabes Tongue. Beirut:Dar Sad.

Imam, I. (1969). Media and mass communication. Cairo: Anglo-Egyptian Library.

Johnpoll, B., \& John, J. (1977). Terrorism and the Mass Media in the United States. Terrorism Interdisciplinary Perspectives Journal, 22(1).

Libda, W. (2005). The Impact of Globalization on Social and Economic Stability in the Arab World (MA Thesis, University of Jordan, Amman, Jordan).

Merrell, J. (1989). Media Means and Message. Riyadh: Dar Al-Marrikh. 
Othman, S. (1986). Social Responsibility and Muslims'Personality. Cairo: Educational Psychological Studies.

Parsons, T. (1984). Functional Theories of Change: Social Change. Damascus: Ministry of Culture.

Schaffert, R. (1992). Media and Society. London:Praeger Publishers.

Stevenson, K., \& Joseph, K. (2003). Monitorial Citizenship and Media Use. School of Journalism and Mass Communication, University of North Carolina.

Turton, A. (1999). Water and Social Stability: The Southern African Dilemma. 49th Pugwash Conference Confronting the Challenges of the 21st Century Working Group No. 5. The Environment.

Ubaid, H. (1996). The importance of social institutions in the maintenance of social security. Symposium on the role of media and education institutions in spreading security awareness and cracking down on crime.

Write, C. (1983). Social Perspective of Mass Communication. Cairo: Egyptian General Book Council.

Zuhair, E. (1993). Introduction to Media and Communication Sciences. Algeria: University Publications Divan.

\section{Copyrights}

Copyright for this article is retained by the author(s), with first publication rights granted to the journal.

This is an open-access article distributed under the terms and conditions of the Creative Commons Attribution license (http://creativecommons.org/licenses/by/4.0/). 